\title{
Primary metabolism and initial development of grafted black pepper seedlings
}

\author{
Metabolismo primário e o desenvolvimento inicial de mudas enxertadas de pimenteira-do-reino \\ Metabolismo primario y desarrollo inicial de plántulas de pimiento negro injertadas
}

Received: 09/16/2021 | Reviewed: 09/23/2021 | Accept: 11/05/2021| Published: 11/08/2021

\author{
Jeane Crasque \\ ORCID: https://orcid.org/0000-0002-2731-4195 \\ Instituto Capixaba de Pesquisa, Assistência Técnica e Extensão Rural, Brazil \\ E-mail: jeanecrasker@gmail.com \\ Sara Dousseau Arantes \\ ORCID: https://orcid.org/ 0000-0001-6202-4153 \\ Instituto Capixaba de Pesquisa, Assistência Técnica e Extensão Rural, Brazil \\ E-mail: sara.arantes@incaper.es.gov.br \\ Basílio Cerri Neto \\ ORCID: https://orcid.org/0000-0002-5778-6185 \\ Instituto Capixaba de Pesquisa, Assistência Técnica e Extensão Rural, Brazil \\ E-mail: basiliocerri@yahoo.com \\ Maria Luiza Pereira Barbosa Pinto \\ ORCID: https://orcid.org/0000-0003-4972-5574 \\ Instituto Capixaba de Pesquisa, Assistência Técnica e Extensão Rural, Brazil \\ E-mail: luiza_14p@hotmail.com \\ Lúcio de Oliveira Arantes \\ ORCID: https://orcid.org/0000-0001-7266-6563 \\ Instituto Capixaba de Pesquisa, Assistência Técnica e Extensão Rural, Brazil \\ E-mail: lucio.arantes@incaper.es.gov.br \\ Thayanne Rangel Ferreira \\ ORCID: https://orcid.org/0000-0002-4856-3887 \\ Instituto Capixaba de Pesquisa, Assistência Técnica e Extensão Rural, Brazil \\ E-mail: thayanne_rangel@ hotmail.com \\ José Altino Machado Filho \\ ORCID: https://orcid.org/0000-0001-7759-2479 \\ Instituto Capixaba de Pesquisa, Assistência Técnica e Extensão Rural, Brazil \\ E-mail: altino@incaper.es.gov.br
}

\begin{abstract}
The production of black pepper seedlings through grafting is a promising strategy to mitigate the effect of environmental stresses, such as drought, that limit its cultivation. However, studies on compatibility between grafts and rootstocks are still scarce, especially considering the wild species of the genus Piper and the cultivated genotypes of black pepper. The objective of this work was to evaluate the relationship between primary metabolism and the development of black pepper seedlings obtained through intra- and interspecific grafting. The method used was that of cleft lateral grafting, as graft the Bragantina cultivar, better known in the world as 'Panniyur 1', and 'Kottanadan' cultivar and three wild species (Piper hispidum, Piper aduncum and Piper tuberculatum) were used as root-stock. As a control, 'Bragantina' was grafted onto itself (homograft). The experiment was carried out for 110 days and the seedlings were evaluated for development, gas exchange, and carbohydrate allocation. The rootstock influences the development and primary metabolism of seedlings. P. aduncum showed greater initial compatibility among wild species, due to less impediment to carbohydrate flow. P. tuberculatum showed early incompatibility, as the grafts died. The seedlings grafted on P. hispidum and 'Kottanadan' had initial compatibility with an average of $78 \%$ survival and $60 \%$ budding, but they may have late incompatibility due to limitation of carbohydrate flow.
\end{abstract}

Keywords: Piper nigrum; 'Bragantina' ('Panniyur 1'); 'Kottanadan'; Piper hispidum; Piper aduncum; Piper tuberculatum.

\section{Resumo}

A produção de mudas da pimenteira-do-reino através da enxertia é uma estratégia promissora para mitigar os efeitos dos estresses ambientais, como a seca, que limitam o seu cultivo. No entanto, ainda são escassos os estudos de compatibilidade entre enxerto e porta-enxerto, principalmente considerando as espécies selvagens do gênero Piper e os genótipos cultivados de pimenteira-do-reino. Objetivou-se com este trabalho avaliar a relação entre o metabolismo primário e o desenvolvimento das mudas da pimenteira-do-reino obtidas através da enxertia intra e interespecífica. $\mathrm{O}$ método empregado foi o de enxertia lateral em fenda cheia, como enxerto foi utilizada a cultivar Bragantina, mais conhecida no mundo como 'Panniyur 1' e como porta-enxerto foram avaliados a cultivar 'Kottanadan' e três espécies selvagens (Piper hispidum, Piper aduncum e Piper tuberculatum). Como controle foi efetuado a enxertia da 
'Bragantina nela mesma (homoenxerto). O experimento foi conduzido durante 110 dias e as mudas foram avaliadas quanto ao desenvolvimento, trocas gasosas e alocação de carboidratos. O porta-enxerto influencia no desenvolvimento e no metabolismo primário das mudas. O porta-enxerto influencia no desenvolvimento e no metabolismo primário das mudas. $P$. aduncum apresentou maior compatibilidade inicial entre as selvagens, devido ao menor impedimento ao fluxo de carboidratos. $P$. tuberculatum apresentou incompatibilidade precoce, pois houve a morte dos enxertos. As mudas enxertadas em $P$. hispidum e a 'Kottanadan tiveram compatibilidade inicial apresentando em média $78 \%$ de sobrevivência e $60 \%$ de brotamento, porém podem ter incompatibilidade tardia por limitação ao fluxo de carboidratos. Palavras-chave: Piper nigrum; 'Bragantina' ('Panniyur 1'); 'Kottanadan'; Piper hispidum; Piper aduncum; Piper tuberculatum.

\begin{abstract}
Resumen
La producción de plántulas de pimienta negra mediante injertos es una estrategia prometedora para mitigar los efectos de las tensiones ambientales que limitan su cultivo. Sin embargo, los estudios de compatibilidad entre injerto y portainjerto son aún escasos, especialmente considerando especies silvestres del género Piper y genotipos de pimienta negra cultivados. El objetivo de este trabajo fue evaluar la relación entre el metabolismo primario y el desarrollo de plántulas de pimienta negra obtenidas mediante injertos intra e interespecíficos. El método utilizado fue elInjerto de enchapado lateral, se utilizó como injerto el cultivar Bragantina, más conocido en el mundo como 'Panniyur 1' y como portainjerto se evaluó el cultivar 'Kottanadan' y tres especies silvestres (Piper hispidum, Piper aduncum y Piper tuberculatum). Como control, se le injertó 'Bragantina' (homoinjerto). El experimento se llevó a cabo durante 110 días y se evaluó el desarrollo, el intercambio de gases y la asignación de carbohidratos de las plántulas. El portainjerto influye en el desarrollo y metabolismo primario de las plántulas. $P$. aduncum mostró una mayor compatibilidad inicial entre las especies silvestres, debido a un menor impedimento para el flujo de carbohidratos. $P$. tuberculatum mostró incompatibilidad temprana, ya que los injertos murieron. Las plántulas injertadas en $P$. hispidum y 'Kottanadan' tenían compatibilidad inicial con un promedio de $78 \%$ de supervivencia y $60 \%$ de brotación, pero pueden tener incompatibilidad tardía debido a la limitación del flujo de carbohidratos.
\end{abstract}

Palabras clave: Piper nigrum; 'Bragantina' ('Panniyur 1'); 'Kottanadan'; Piper hispidum; Piper aduncum; Piper tuberculatum.

\title{
1. Introduction
}

Black pepper is the major spice produced worldwide. It is known as the "King of Spices" (Joshi et al., 2018). Brazil stands out in the international ranking in the production of this spice as it was considered the third-largest producer in 2017 (FAO, 2019). According to the Brazilian Institute of Geography and Statistics (IBGE), the area harvested in Brazil in 2018 was approximately 34,299 ha and the production was 1,012,741 t (IBGE, 2019). Although Brazil is the world' sleading producer of black pepper, the average yield is very low, about $85 \%$ lower than the countries with the highest yield, Vietnam and Indonesia (FAO, 2019). Among the factors that restrict Brazilian productivity, it is mentioned the incidence of the fungus Fusarium solani f. sp. Piperis attacks the root system and rapidly spreads in the field, resulting in the death of the plants (Trindade et al., 2021). Currently, there are no sources of resistance to Fusarium sp. is in pepper cultivars developed all over the world. Chemical control strategies are not very efficient. In addition, it raises the cost of cultivation and causes environmental pollution and health risks (Khayatnezhad \& Nasehi, 2021).

An alternative for the cultivation of black pepper in contaminated areas is to use resistant wild species of the genus Piper as a rootstock for commercial cultivars. Although the source of resistance of the genus Piper has still been little explored, as it can be seen the small number of evaluated species in comparison to the hundreds of this genus, some wild species have been considered resistant to fusarium, such as Piper colubrinum Link, Piper aduncum Linn., Piper tuberculatum L Jacq., Piper hispidinervium C.DC., Piper hispidum Sw and Piper reticulatum (Albuquerque et al., 2001; Bastos et al., 2016).

The production of black pepper seedlings grafted on wild species has been considered possible to be achieved; however, the response depends on the interaction between the graft with the rootstock. In countries such as India, the grafting of black pepper on Piper colubrinum is a widespread practice of seedling production, aiming to overcome biotic and abiotic stresses (Vanaja et al., 2007). Cultivar Panniyur 1, in Brazil registered as 'Bragantina' (Schmildt et al., 2018), is the main genotype of black pepper cultivated worldwide and although several studies indicate that it is possible to graft this cultivar into 
wild species (Vanaja et al., 2007; Lakshmana et al., 2016; Aarthi \& Kumar, 2019). There is evidence of late incompatibility in black pepper was reported by Alconero et al. (1972) and Barriga et al. (1986), where the plants obtained by grafting between Piper nigrum and the rootstock $P$. colubrinum died after four years. Therefore, further studies are needed between commercial cultivars of black pepper grafted on native species in Brazil, considering the producing regions, for a better understanding of the effect of the environment.

Grafting has positive effects related to the translocation of primary metabolites that improve seedling growth, development and survival (Thies, 2021). Primary metabolics are the main compounds produced by plants, such as proteins, carbohydrates, enzymes, lipids and chlorophylls (Poorni et al., 2019). In grafting, the rootstocks regulate the primary metabolites (Vidoy-Mercado et al., 2021), increasing the flow efficiency due to the modification of the xylem translocation and physiological processes of the crown, improving the plant vigor (Amri et al., 2021; Thies, 2021). Although studies report that graft compatibility depends on the interaction between graft and rootstock, it is still necessary to elucidate the mechanisms related to the incompatibility. Thus, the primary metabolites can serve as important markers for a better understanding of the formation of graft union in black pepper. Therefore, the objective of this study was to evaluate the relationship between primary metabolism and development of black pepper seedlings obtained through intra and interspecific grafting, aiming to identify compatible rootstocks and elucidate mechanisms involved in incompatibility.

\section{Methodology}

\subsection{Plant Material and Growth Conditions}

The experiment was carried out at the Capixaba Institute for Technical Assistance and Rural Extension Research (INCAPER), Linhares, Espírito Santo, Brazil (19²5'00.49 " S - $40^{\circ} 04$ '38.52' 'W). According to to Köppen (1936), the region has an irregular regime of rainfall with high temperatures, being classified as Tropical Aw. During the experimental period (July 2018 to June 2019), climatic data were collected in the automatic weather station of Linhares / ES, where the average values of maximum, minimum, and average temperature, rainfall, and relative humidity were $30.24^{\circ} \mathrm{C}, 21.28^{\circ} \mathrm{C}, 24.75^{\circ} \mathrm{C}, 2.51$ $\mathrm{mm}$ and $75.78 \%$, respectively.

For graft, 'Bragantina' was used and 'Kottanadan' and three native species (Piper hispidum, Piper aduncum, and Piper tuberculatum) were used as rootstock. As a control, the cultivar 'Bragantina' was grafted on itself, which is considered a homograft.

In the first experimental step, the rootstock seedlings were produced using seedlings from parent plants of the Active Germplasm Bank (BAG) of INCAPER. Seedlings of native species were obtained using the protocol proposed by Dousseau et al. (2011) with modifications, where germination was carried out in a BOD-chamber and the seedlings were transferred after 40 days to a styrofoam tray with 200 cells, containing commercial organic substrate (Bioplant ${ }^{\circledR}$ ), maintained for 60 days in a nursery covered with shade $(50 \%)$ and transplanted to tubes with a capacity of $280 \mathrm{~cm}^{3}$ filled with commercial organic substrate, fertilized with $2 \mathrm{~g}$ of slow-release fertilizer 3 to 4 months (Osmocote ${ }^{\circledR}$ ), where they remained for another 48 days. After this period, grafting was performed (234 days after sowing).

Seedlings of black pepper cultivars were produced as described in Ambrozim et al. (2017) with adaptations. Herbaceous cuttings with one node and two leaves were used, collected from the median region of the branch, which were disinfected through immersion in a fungicide solution for 5 minutes, followed by immersion for 12 hours in a solution containing $400 \mathrm{mg} \mathrm{L}^{-1}$ of the growth regulator butyric indole acid. The grafting in the cultivars was done at 160 days after staking.

Grafting was carried out between February and June 2019. The average values of maximum, minimum, and average temperature, rainfall, and relative humidity were recorded during these periods which were $32.05^{\circ} \mathrm{C}, 23.01^{\circ} \mathrm{C}, 26.36^{\circ} \mathrm{C}, 2.12$ 
$\mathrm{mm}, 74.59 \%$, respectively. The graft was obtained from cuttings collected from 2 -year-old mother plants, in a commercial field, located in the municipality of Linhares-ES, located at $19^{\circ} 24^{\prime} 51^{\prime \prime} \mathrm{S}$ and $40^{\circ} 13^{\prime} 37^{\prime \prime} \mathrm{W}$. The orthotropic branches were collected and kept moist for 24 hours in moist-burlap bags. Grafts were prepared to contain two leafless nodes from herbaceous branches. The grafting method used was lateral forking and the procedure was performed by an experienced grafter, from $07 \mathrm{~h} 00$ to $12 \mathrm{~h} 00$.

The rootstock was prepared by making a $3-\mathrm{cm}$ side cut at the height of the fourth node, from the neck of the seedling. In the graft, a double bevel-wedge was made, with $3 \mathrm{~cm}$, and after insertion in the rootstock, fastening was performed with a No. 18-rubber elastic. Immediately after the grafting procedure, the spray was carried out with fungicide Carbendazin (active principle), and the graft was covered with transparent $6 \times 23 \mathrm{~cm}$ plastics tied just below the grafting point. Between 28 and 30 days after the first open leaf appeared, the plastic bags were removed and after 15 days, the aerial part of the rootstock was decapitated. After grafting, the seedlings were kept in the nursery with a $50 \%$ shade screen with sprinkler irrigation for a period of 110 days.

The percentage of survival was calculated from weekly evaluations, considering the total graft dryness and after 95 days of grafting, the incidence of graft shooting was evaluated. After 110 days of grafting, an evaluation was made regarding the development of seedlings, gas exchange, the levels of photosynthetic pigments, and the quantity of allocated carbohydrates.

\subsection{Plant Growth Parameters and SPAD Index}

Seedling development was evaluated with ten plants from each plot, which had their substrate removed in tapwater. The seedlings were taken to the Plant Physiology and Post-Harvest Laboratory (LFVPC) of INCAPER, where the following were evaluated: shoot stem length $\left(\mathrm{SL}_{\text {shoot}}\right)$, root length $(\mathrm{RL})$, shoot stem diameter (SDshoot), number of leaves $(\mathrm{NL})$, leaf area $(\mathrm{LA})$, stem diameter above the grafting point $\left(\mathrm{SD}_{\mathrm{ab}}\right)$, stem diameter below the grafting point $\left(\mathrm{SD}_{\mathrm{bl}}\right)$, root volume (RV), allocation of the dry mass and SPAD index. The leaf area was obtained using the leaf area meter (Li-Cor, model 3100). The SPAD index (green color intensity) was evaluated with a fully expanded leaf and two plants per plot using a Portable Chlorophyll Meter, model SPAD-502 "Soil Plant Analyzer Development” (Minolta, Japan).

Dry mass was allocated through by seedling cutting and drying it in aforced air circulation oven at $65^{\circ} \mathrm{C}$ until constant weight. The values of the dry mass of the leaves $\left(\mathrm{DM}_{\text {leaf }}\right)$, of the stem of the shoot $\left(\mathrm{SDM}_{\text {shoot }}\right)$, of the stem above the grafting point $\left(\mathrm{SDM}_{\mathrm{ab}}\right)$ (corresponds to the graft cut), of the stem below the grafting point $\left(\mathrm{SDM}_{\mathrm{bl}}\right)$, of the rootstock cutting $\left(\mathrm{DM}_{\text {cutting }}\right)$ and of the roots $\left(\mathrm{DM}_{\mathrm{roots}}\right)$. These data were used to calculate the dry mass of the grafted stem ( $\left.\mathrm{SDM}_{\mathrm{graf}}\right)$ through the sum of the $\mathrm{SDM}_{\text {shoot }}$ and $\mathrm{SDM}_{\mathrm{ab}}$; rootstock dry mass (RSSDM) through the sum of $\mathrm{SDM}_{\mathrm{bl}}$ and DMcutting; the dry mass of the aerial part of the seedling (APDM) through the of $\mathrm{DM}_{\text {leaf }}, \mathrm{SDM}_{\text {graf }}$ and RSSDM, and the total dry mass (TDM).

\subsection{Leaf Gas Exchange}

Gas exchanges were evaluated in two plants per plot, on a fully expanded leaf, using the portable (Li-Cor, model LI6400) infrared (IRGA) gas analyzer. The analyses were carried out between $08 \mathrm{~h} 00$ and $10 \mathrm{~h} 00$ under saturating light with a photosynthetically active photon flux density of $1,200 \mu \mathrm{mol} \mathrm{m} \mathrm{m}^{-2} \mathrm{~s}^{-1}$ and under conditions of $25^{\circ} \mathrm{C}$ and $\mathrm{CO}_{2}$ of $400 \mathrm{ppm}$, where the following characteristics were evaluated: photosynthetic rate $(A)$, transpiration $(E)$, stomatal conductance $(g s)$ and internal concentration of $\mathrm{CO}_{2}(\mathrm{Ci})$. Based on these data, the ratio between the internal-external $\mathrm{CO}_{2}$ concentration $(\mathrm{Ci} / \mathrm{Ca})$, water use efficiency (WUE- $A / E$ ), instant water use efficiency (EiWU-A/gs), instant carboxylation efficiency (EiC - $A / C i)$. 


\subsection{Analysis of photosynthetic Pigments}

The photosynthetic pigments were extracted from fully expanded leaves, using the methodologies proposed by Arnon (1949) for chlorophylls and Rodriguez-Amaya and Kimura (2004) for carotenoids. The leaves were collected and immediately taken to Plant Physiology and Post-Harvest Laboratory at Incaper. For the extraction of chlorophylls and carotenoids, 2 and 4 2-mm discs were used respectively. The discs were weighed and the pigment content was expressed in $\mu \mathrm{g} / \mathrm{ml}$ of fresh mass. The readings were taken on a spectrophotometer (Beckman, model 640B).

\subsection{Analysis of carbohydrates}

The allocation of carbohydrates was evaluated through the quantification of reducing sugars (RS), total soluble sugars (TSS), and leaf starch, stem above and below the grafting point and roots. The plant tissues used for dry mass evaluation were ground in a Willie-knife mill, model STAR FT-50, stored in a freezer at $-18^{\circ} \mathrm{C}$. The extracts were obtained according to Zanandrea et al. (2009), using variable mass, $0.15 \mathrm{~g}$ (leaf and stem below the grafting point); $0.1 \mathrm{~g}$ (stem below the grafting point), $0.3 \mathrm{~g}$ (cultivar root), and $0.4 \mathrm{~g}$ (wild plants root).

For the quantification of TSS and starch, the Antrona method (Yemm et al., 1954) was used, with modifications, using $2 \mathrm{ml}$ of the $0.19 \%$ antrona solution in $93.33 \%$ sulfuric acid, in a volume $3 \mathrm{~mL}$ reaction tube, subjected to $100{ }^{\circ} \mathrm{C}$ for 3 minutes. Reducing sugars were quantified according to the protocol described by Miller (1959), using the Dinitrosalicylic Acid (DNS) method.

\subsection{Statistical Analyses}

The experimental design was organized in randomized blocks, totaling 5 treatments and 4 repetitions, containing 25 seedlings per plot. Data were subjected to analysis of variance and the means grouped by the Scott-Knott test at 5\% probability, using the statistical program SISVAR version 5.6 (Ferreira, 2011). The relationship between the diameters above and below the grafting point was evaluated considering a simple factorial $4 \times 2$ (4 rootstocks $\mathrm{x}$ two measurement positions of the stem diameter). The allocation of carbohydrates was evaluated considering a double factorial $4 x 4$, with 4 rootstocks and 4 organs (leaves, stem above and below the grafting point and roots). To analyze the relationship between primary metabolism (gas exchange and carbohydrates) with seedling development, Pearson's correlation coefficient was obtained, using the treatment means, with the aid of the statistical program PAST version 3.25 (Hammer et al., 2001).

\section{Results}

The use of 'Bragantina', 'Kottanadan' P. hispidum, and P. aduncum, as rootstock showed 78\% survival (Figure 2 A) and $60 \%$ shooting, on average (Figure $2 \mathrm{~B}$ ). The use of $P$. tuberculatum as a rootstock did not allow the formation of the aerial part. Although the rootstock was alive, emitting shoots at the base of the stem, the connection at the grafting point did not occur properly (Figure 1), resulting in the elimination of the graft over time (Figure $2 \mathrm{~A}$ ). The percentage of survival had the lowest value, $34.5 \%$ (Figure $2 \mathrm{~A}$ ), with no total shooting (Figure $2 \mathrm{~B}$ ). 
Figure 1. 'Bragantina' black pepper seedlings grafted under different rootstocks. P. nigrum 'Bragantina' (A), P. nigrum 'Kottanadan' (B), Piper hispidum (C), Piper aduncum (D), Piper tuberculatum (E), after 110 days.

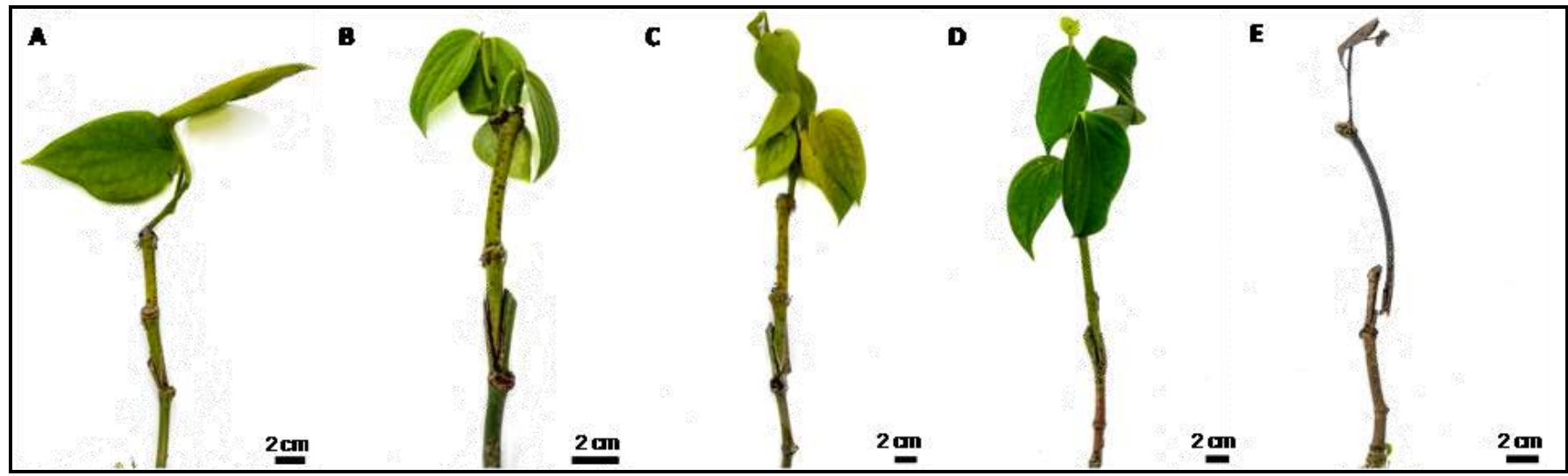

The bar corresponds to $2 \mathrm{~cm}$. Source: Authors.

It can be seen in Figure 2 that the death of the grafts started when the bag was removed, about 30 days after the grafting procedure, when the graft shooting had started. It is also observed that at the time of the beheading of the aerial part of the graft (45 days after the grafting), the deaths intensified, including the formed shoots that suffered abscission.

Figure 2. Evaluation of the 'Bragantina' pepper seedlings grafted on different rootstocks. Survival \% (A), Shooting \% (B).
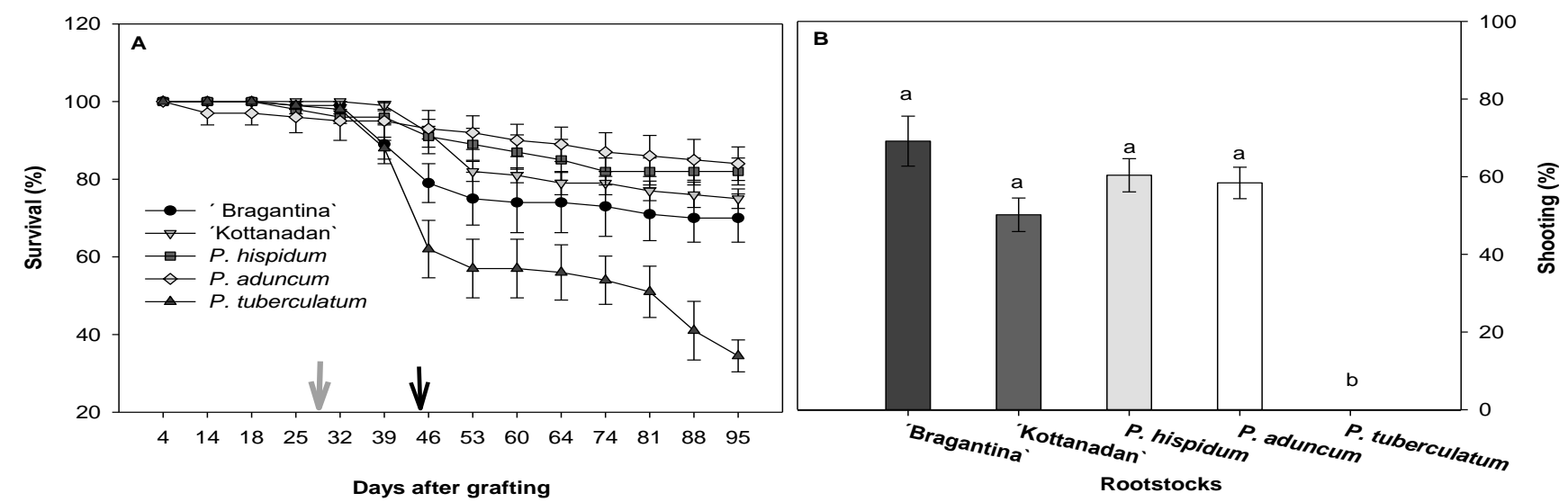

Means followed by the same letter do not differ according to the Scott-Knott cluster test at $5 \%$ probability. The bar corresponds to the standard error of the mean of four replicates. Gray arrow indicates removal of the pouch, approximately 30 days after the grafting procedure, and black arrow indicates the moment of decapitation of the aerial part of the graft at 45 days after grafting. Source: Authors.

The rootstocks in this experimentshowed no significant difference in the $\mathrm{SL}_{\text {shoot, }} \mathrm{SD}_{\text {shoot}}, \mathrm{NL}, \mathrm{LA}, \mathrm{SD}_{\mathrm{ab}}$, and RV (Table 1). The rootstock $P$. hispidum showed the longest RL, with values around $50 \%$ higher than the others. The largest $\mathrm{SD}_{\mathrm{bl}}$ was obtained with the rootstock $P$. aduncum. 
Table 1. Development of 'Bragantina' black pepper seedlings grafted on different rootstocks. Shoot stem length (SLshoot), root length (RL), shoot stem diameter ( $\mathrm{SD}_{\text {shoot}}$ ), number of leaves $(\mathrm{NL})$, leaf area (LA), stem diameter above the grafting point $\left(\mathrm{SD}_{\mathrm{ab}}\right)$, stem diameter below the grafting point $\left(\mathrm{SD}_{\mathrm{bl}}\right)$, root volume $(\mathrm{RV})$.

\begin{tabular}{|c|c|c|c|c|c|c|c|c|}
\hline Rootstock & $\mathrm{SL}_{\text {shoot }}(\mathrm{cm})$ & $\mathbf{R L}(\mathbf{c m})$ & $\begin{array}{c}\text { SDSноOт } \\
(\mathrm{mm})\end{array}$ & NL & $\mathbf{L A}\left(\mathbf{c m}^{2}\right)$ & $\begin{array}{l}\mathrm{SD}_{\mathrm{ab}} \\
(\mathrm{mm})\end{array}$ & $\begin{array}{l}\mathrm{SD}_{\mathrm{bl}} \\
(\mathrm{mm})\end{array}$ & $\mathbf{R V}\left(\mathbf{m}^{3}\right)$ \\
\hline 'Bragantina' & $7.4 \mathrm{a}$ & $26.6 \mathrm{~b}$ & $3.9 \mathrm{a}$ & $3.0 \mathrm{a}$ & $129.6 \mathrm{a}$ & $6.5 \mathrm{a}$ & $6.1 \mathrm{~b}$ & $396.8 \mathrm{a}$ \\
\hline 'Kottanadan' & $6.8 \mathrm{a}$ & $23.9 \mathrm{~b}$ & $3.5 \mathrm{a}$ & $2.8 \mathrm{a}$ & $90.8 \mathrm{a}$ & $6.4 \mathrm{a}$ & $5.7 \mathrm{~b}$ & $506.7 \mathrm{a}$ \\
\hline P. hispidum & $8.9 \mathrm{a}$ & $40.2 \mathrm{a}$ & $3.6 \mathrm{a}$ & $3.8 \mathrm{a}$ & $97.0 \mathrm{a}$ & $6.3 \mathrm{a}$ & $5.6 \mathrm{~b}$ & $419.2 \mathrm{a}$ \\
\hline P. aduncum & $6.6 \mathrm{a}$ & $22.9 \mathrm{~b}$ & $3.9 \mathrm{a}$ & $3.3 \mathrm{a}$ & $110.4 \mathrm{a}$ & $6.6 \mathrm{a}$ & $7.1 \mathrm{a}$ & $418.9 \mathrm{a}$ \\
\hline $\mathrm{CV}(\%)$ & 43.3 & 5.7 & 12.7 & 33.4 & 38.9 & 4.2 & 6.2 & 22.9 \\
\hline
\end{tabular}

Means followed by the same letter in the column do not differ by the Scott-Knott cluster test at 5\% probability. Source: Authors.

No significant differences were observed in the accumulation of $\mathrm{DM}_{\text {leaf }}$, in the $\mathrm{SDM}_{\text {shoot}}$, in the $\mathrm{SDM}_{\mathrm{ab}}$, and the $\mathrm{SDM}_{\text {graft }}$ (Table 2). The SDM $\mathrm{bl}$ was lower in the cultivars. The APDM and the was higher in the cultivars in relation to wild species, due to the presence of the $\mathrm{DM}_{\text {cutting, }}$ resulting from the cutting process for obtaining rootstocks for cultivars. 'Kottanadan`allocated less $\mathrm{DM}_{\text {roots, }}$, contributing to the lower TDM.

Table 2. Allocation of dry mass (g), obtained from 'Bragantina' black pepper seedlings grafted on different rootstocks. Leaf dry matter $\left(\mathrm{DM}_{\text {leaf }}\right)$, shoot stem dry mass $\left(\mathrm{SDM}_{\text {shoot }}\right)$, dry matter of the stem above grafting point $\left(\mathrm{SDM}_{\mathrm{ab}}\right)$, graft stem dry mass $\left(\mathrm{SDM}_{\text {graft }}\right)$, dry mass of the stem below grafting point $\left(\mathrm{SDM}_{\mathrm{bl}}\right)$, cutting dry mass $\left(\mathrm{DM}_{\text {cutting }}\right)$, rootstock dry mass $\left(\mathrm{SDM} \mathrm{rs}_{\mathrm{r}}\right)$, seedling aerial part dry mass (APDM), root dry mass (DM root , total dry mass (TDM).

\begin{tabular}{ccccccccccc}
\hline Rootstock & DM $_{\text {leaf }}$ & SDM $_{\text {shoot }}$ & SDM $_{\mathbf{a b}}$ & SDM $_{\text {graft }}$ & SDM $_{\mathrm{bl}}$ & DM $_{\text {cutting }}$ & SDM $_{\mathbf{r s}}$ & APDM & DMroot & TDM \\
\hline 'Bragantina & $8.54 \mathrm{a}$ & $1.41 \mathrm{a}$ & $9.29 \mathrm{a}$ & $10.70 \mathrm{a}$ & $4.92 \mathrm{~b}$ & $19.00 \mathrm{a}$ & $23.92 \mathrm{a}$ & $43.16 \mathrm{a}$ & $20.28 \mathrm{a}$ & $63.44 \mathrm{a}$ \\
'Kottanadan' $^{2}$ & $5.64 \mathrm{a}$ & $1.15 \mathrm{a}$ & $8.37 \mathrm{a}$ & $9.52 \mathrm{a}$ & $4.43 \mathrm{~b}$ & $19.93 \mathrm{a}$ & $24.35 \mathrm{a}$ & $39.52 \mathrm{a}$ & $7.07 \mathrm{~b}$ & $46.58 \mathrm{~b}$ \\
$\boldsymbol{P}$. hispidum & $7.13 \mathrm{a}$ & $2.05 \mathrm{a}$ & $8.79 \mathrm{a}$ & $10.84 \mathrm{a}$ & $9.42 \mathrm{a}$ & - & $9.42 \mathrm{~b}$ & $27.39 \mathrm{~b}$ & $25.59 \mathrm{a}$ & $52.98 \mathrm{a}$ \\
$\boldsymbol{P}$. $\boldsymbol{a d u n c u m}$ & $4.95 \mathrm{a}$ & $0.96 \mathrm{a}$ & $7.49 \mathrm{a}$ & $8.46 \mathrm{a}$ & $10.44 \mathrm{a}$ & - & $10.44 \mathrm{~b}$ & $23.85 \mathrm{~b}$ & $21.74 \mathrm{a}$ & $45.58 \mathrm{a}$ \\
\hline CV (\%) & 50.60 & 65.90 & 9.30 & 22.71 & 11.85 & 22.20 & 14.60 & 15.80 & 35.70 & 9.28 \\
\hline
\end{tabular}

Means followed by the same letter in the column do not differ by the Scott-Knott cluster test at 5\% probability. Source: Authors.

The rootstocks in the experiment did not influence the gas exchange parameters (Table 3), the chlorophyll content, and the SPAD index (Table 4) of 'Bragantina' pepper leaves. Carotenoid contents were higher in rootstocks in comparison to the homograft, except for $\alpha$-Carotene, which did not differ (Table 4). 
Table 3. Gas exchange of 'Bragantina' black pepper seedlings grafted on different rootstocks. Photosynthetic rate $(A)$, Transpiration $(E)$ Stomatal conductance $\left(g_{s}\right)$, Internal $\mathrm{CO}_{2}$ concentration $\left(\mathrm{C}_{\mathrm{i}}\right)$, Ratio between the internal and external concentration of $\mathrm{CO}_{2}\left(\mathrm{C}_{\mathrm{i}} / \mathrm{C}_{\mathrm{a}}\right)$, Water use efficiency (WUE- $A / E$ ), Instant water use efficiency (EiWU- $A / g s$ ), Instant carboxylation efficiency $(\mathrm{EiC}-\mathrm{A} / \mathrm{Ci})$.

\begin{tabular}{|c|c|c|c|c|c|c|c|c|}
\hline Rootstock & $A$ & $E$ & $g_{s}$ & $\mathbf{C}_{\mathrm{i}}$ & $\mathbf{C}_{\mathrm{i}} / \mathbf{C}_{\mathbf{a}}$ & WUE & EiWU & EiC \\
\hline 'Bragantina' & $5.7 \mathrm{a}$ & $2.6 \mathrm{a}$ & $0.2 \mathrm{a}$ & $323.8 \mathrm{a}$ & $0.8 \mathrm{a}$ & $2.3 \mathrm{a}$ & $35.3 \mathrm{a}$ & $0.1 \mathrm{a}$ \\
\hline 'Kottanadan' & $6.1 \mathrm{a}$ & $2.5 \mathrm{a}$ & $0.2 \mathrm{a}$ & $304.0 \mathrm{a}$ & $0.8 \mathrm{a}$ & $2.9 \mathrm{a}$ & $47.3 \mathrm{a}$ & $0.2 \mathrm{a}$ \\
\hline P. hispidum & $7.2 \mathrm{a}$ & $2.9 \mathrm{a}$ & $0.2 \mathrm{a}$ & $314.8 \mathrm{a}$ & $0.8 \mathrm{a}$ & $2.6 \mathrm{a}$ & $39.5 \mathrm{a}$ & $0.1 \mathrm{a}$ \\
\hline P. aduncum & $7.5 \mathrm{a}$ & $2.6 \mathrm{a}$ & $0.2 \mathrm{a}$ & $300.5 \mathrm{a}$ & $0.8 \mathrm{a}$ & $3.2 \mathrm{a}$ & $48.2 \mathrm{a}$ & $0.2 \mathrm{a}$ \\
\hline CV (\%) & 17.08 & 18.21 & 23.49 & 8.13 & 7.98 & 33.40 & 35.76 & 57.00 \\
\hline
\end{tabular}

Means followed by the same letter in the column do not differ by the Scott-Knott cluster test at 5\% probability. Source: Authors.

Table 4. Photosynthetic pigment content, expressed in $\mu \mathrm{g} \mathrm{g}^{-1}$ of fresh mass of 'Bragantina' black pepper seedlings grafted on different rootstocks. Chlorophyll a (Cla), chlorophyll b ( $\mathrm{Clb})$, total chlorophyll $(\mathrm{Cl}$ total), $\beta$-Carotene ( $\beta$-Carot.), Zeaxanthin (Zeax.), $\alpha-$ Carotene ( $\alpha$-Carot.), $\beta$ - Cryptoxanthin ( $\beta$-Cript.), Total carotenoids (Total carot.), SPAD index (SPAD).

\begin{tabular}{|c|c|c|c|c|c|c|c|c|c|c|}
\hline Rootstock & $\mathrm{Cla}$ & $\mathrm{Cl} b$ & Cl total & $\begin{array}{c}\beta-\text { Caro } \\
\text { t. }\end{array}$ & Licopene & Zeax. & $\begin{array}{c}\alpha-\text { Caro } \\
\text { t. }\end{array}$ & $\begin{array}{c}\beta- \\
\text { Cript. }\end{array}$ & $\begin{array}{l}\text { Total } \\
\text { carot. }\end{array}$ & SPAD \\
\hline 'Bragantina' & $6.9 \mathrm{a}$ & $6.5 \mathrm{a}$ & $13.4 \mathrm{a}$ & $27.9 \mathrm{~b}$ & $19.5 \mathrm{~b}$ & $31.4 \mathrm{~b}$ & $29.3 \mathrm{a}$ & $30.9 \mathrm{~b}$ & $139.13 \mathrm{~b}$ & $39.3 \mathrm{a}$ \\
\hline 'Kottanadan' & $5.8 \mathrm{a}$ & $4.2 \mathrm{a}$ & $10.0 \mathrm{a}$ & $35.7 \mathrm{a}$ & $25.5 \mathrm{a}$ & $40.7 \mathrm{a}$ & $36.3 \mathrm{a}$ & $40.0 \mathrm{a}$ & $178.2 \mathrm{a}$ & $38.0 \mathrm{a}$ \\
\hline P. hispidum & $4.1 \mathrm{a}$ & $3.7 \mathrm{a}$ & $7.8 \mathrm{a}$ & $33.7 \mathrm{a}$ & $23.8 \mathrm{a}$ & $38.3 \mathrm{a}$ & $34.1 \mathrm{a}$ & $37.7 \mathrm{a}$ & $167.6 \mathrm{a}$ & $40.9 \mathrm{a}$ \\
\hline P. aduncum & $6.9 \mathrm{a}$ & $5.9 \mathrm{a}$ & $12.9 \mathrm{a}$ & $36.5 \mathrm{a}$ & $25.5 \mathrm{a}$ & $41.5 \mathrm{a}$ & 36.9 a & $40.8 \mathrm{a}$ & $167.6 \mathrm{a}$ & $48.7 \mathrm{a}$ \\
\hline CV (\%) & 51.4 & 49.4 & 23.5 & 10.9 & 11.4 & 11.0 & 11.2 & 11.0 & 10.9 & 12.2 \\
\hline
\end{tabular}

Means followed by the same letter in the column do not differ by the Scott-Knott cluster test at $5 \%$ probability. Source: Authors.

The relationship between the diameters above and below the grafting point was influenced by the rootstocks, where only the homograft did not show any significant differences (Figure $3 \mathrm{~A}$ ). For the other evaluated rootstocks, the behavior was different. For $P$. aduncum, the diameter below was greater than the diameter above the grafting point, while the opposite was observed for P. hispidum and 'Kottanadan'.

Carbohydrate contents differed between rootstocks considering the evaluated organs, except for starch, which varied only among the plant organs (Figures 3 B, C, and D). The content of RS and TSS in the leaves and roots did not differ between the rootstocks (Figure $3 \mathrm{~B}, \mathrm{C}$ ). The homograft had a greater accumulation of RS and TSS in the stem below the grafting point in relation to the evaluated rootstocks. In the stem above the grafting point, the lowest content of RS was obtained with the rootstock $P$. aduncum.

The allocation of carbohydrates in the different evaluated organs was influenced by the rootstocks, but with different patterns (Figures $3 \mathrm{~B}, \mathrm{C}$, and D). In the homograft, the RS and TSS were higher in the stem above, followed by the leaves and stem below, which did not differ, and lower in the root. With the use of the rootstock P. hispidum, RS and TSS were higher in the stem above, followed by the leaves and stem below and roots, which did not differ. For 'Kottanadan', the same behavior as P. hispidum was observed for RS, however, TSS were superior in leaves and stem above, which did not differ, followed by 
stem below and roots. In P. aduncum, RS was higher in the leaves and the stem above, while TSS was higher in the leaves and in the stem below.

Figure 3. Comparison between stem diameters above and below the grafting point and carbohydrate allocation in 'Bragantina' black pepper seedlings grafted onto different rootstocks. Stem diameters above $\left(\mathrm{SD}_{\mathrm{ab}}\right)$ and below $\left(\mathrm{SD}_{\mathrm{bl}}\right)$ the grafting point $(\mathrm{A})$, Reducing sugars (RS) (B), Total soluble sugars (TSS) (C), Starch (D).
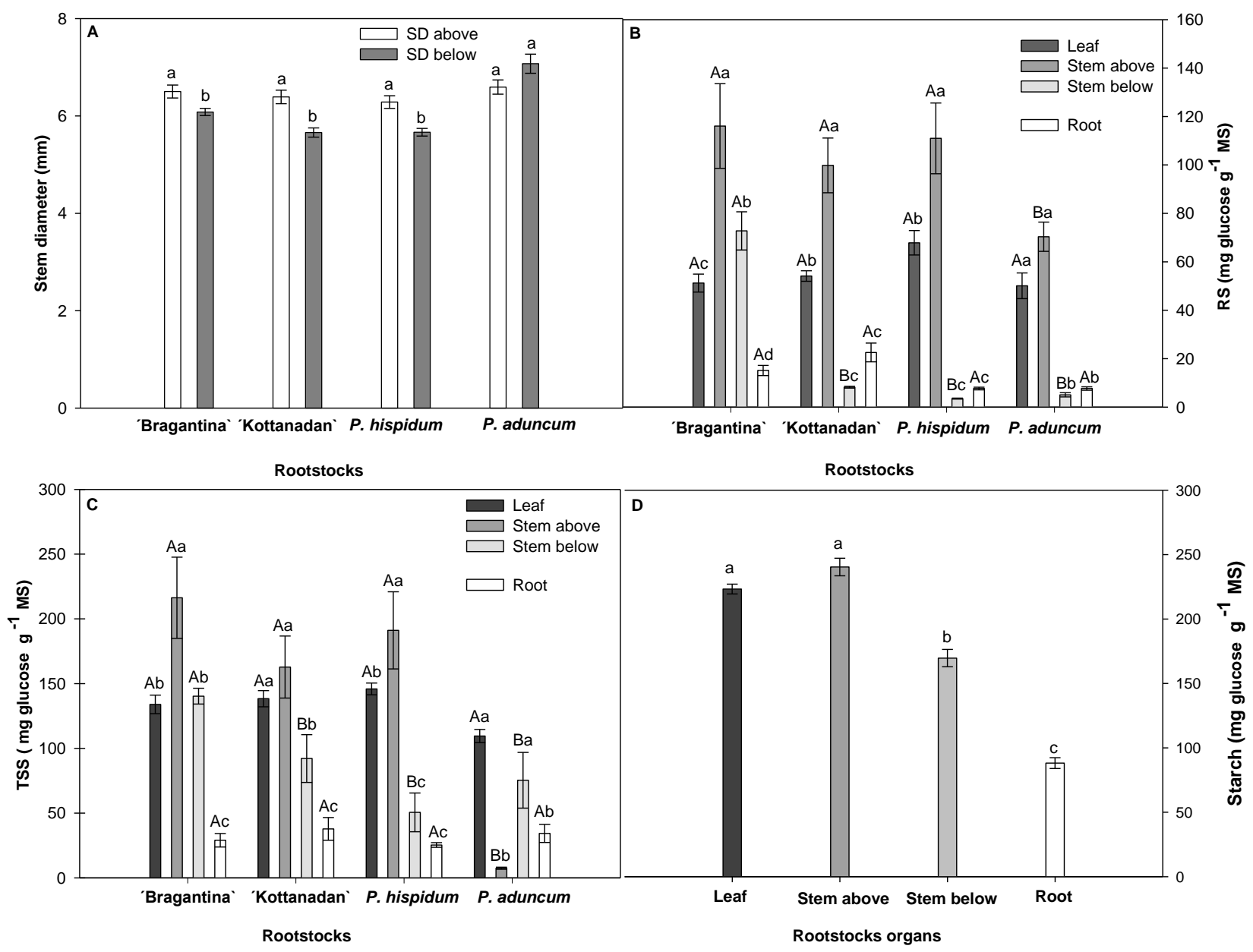

Means followed by the same letters do not differ by the Scott-Knott cluster test at 5\% probability. Lower case letters in Figure A compare diameters between rootstocks. In Figures B and C, upper-case letters compare between rootstocks for each organ and lower-case letters compare between the organs in the rootstock. The bar corresponds to the standard error of the mean of three replicates. Source: Authors.

For the starch content, no interaction between rootstocks and organs was observed. Only the effect of the organs was significant, with higher values for leaves and stem above, which did not differ, followed by the stem below and the roots (Figure 3 D).

In the correlation study, positive and negative relationships were observed between the variables analyzed in the grafting study (Figure 4). Survival was positively correlated with the photosynthetic rate and inversely proportional to the dry mass of the aerial part. Shooting was positively correlated with the starch content of the stem below the grafting point.

The stem length of the shoothad a positive correlation with number of leaves, dry mass of the stem, stomatal conductance, and transpiration. The number of leaves correlated positively with the content of reducing sugars in the leaves and with the root length. The dry mass of the leaves was directly proportional to the total dry mass, internal $\mathrm{CO}_{2}$ 
concentration, ratio between the internal and external $\mathrm{CO}_{2}$ concentration, and inversely proportional to the intrinsic and instantaneous efficiency in the use of water and the levels of carotenoids (except lycopene).

The dry mass of the stem above the grafting point was directly proportional to the RS and TSS content of the stem above the grafting point and inversely proportional to the WUE. The dry mass of the stem below the grafting point correlated positively with the photosynthetic rate and negatively with the dry mass of the cuttings, the rootstock stem and the aerial part of the seedling.

The stem diameter of the shoot was strongly correlated with the starch content accumulated in the stem above the grafting point. The stem diameter above correlated positively with the root starch, while the stem diameter below the grafting point was inversely proportional to the total soluble sugars of the leaf. The dry mass of the stem above the grafting point was directly proportional to the content of reducing and total soluble sugars in the stem above the grafting point and inversely proportional to the intrinsic efficiency in the use of water.

Figure 4. Pearson's correlation matrix between primary metabolism (gas exchange and carbohydrates) with seedling growth. Survival, shooting, length of the stem of the shoot $\left(\mathrm{SL}_{\text {shoot }}\right)$, diameter of the stem of the shoot $\left(\mathrm{SD}_{\text {shoot }}\right)$, number of leaves $(\mathrm{NL})$, leaf area (LA), stem diameter above grafting point $\left(\mathrm{SD}_{\mathrm{ab}}\right)$ and below grafting point $\left(\mathrm{SD}_{\mathrm{bl}}\right)$, root length (RL), root volume (RV), leafdry matter $\left(\mathrm{DM}_{\text {leaf }}\right)$, shoot stem dry mass $\left(\mathrm{SDM}_{\text {shoot }}\right)$, stem dry mass above grafting point $\left(\mathrm{SDM}_{\mathrm{ab}}\right)$, graft stem dry mass $\left(\mathrm{SDM}_{\mathrm{graf}}\right)$, stem dry mass below the grafting point $\left(\mathrm{SDM}_{\mathrm{bl}}\right)$, cutting dry mass $\left(\mathrm{DM}_{\text {cutting }}\right)$, rootstock dry mass $\left(\mathrm{DM}_{\mathrm{RS}}\right)$, aerial part dry mass $(\mathrm{APDM})$, root dry mass $\left(\mathrm{DM}_{\text {root }}\right)$, total dry mass $(\mathrm{TDM})$, photosynthetic rate $(A)$, stomatal conductance $\left(g_{s}\right)$, $\mathrm{CO}_{2}$ inner concentration $\left(\mathrm{C}_{\mathrm{i}}\right)$, transpiration $(E)$, ratio between the internal and external concentration of $\mathrm{CO}_{2}\left(\mathrm{C}_{\mathrm{i}} / \mathrm{C}_{\mathrm{a}}\right)$, water use efficiency (WUE- A/E), water use instantaneous efficiency (WUEi- $A / \mathrm{gs}$ ), carboxylation instantaneous efficiency (EiC - $A / \mathrm{Ci}$ ), $\beta$-Carotene ( $\beta$-Carot.), Lycopene, Zeaxanthin (Zeax.), $\alpha$-Carotene ( $\alpha$-Carot.), $\beta$-Cryptoxanthin ( $\beta$-Crypt.), total Carotenoids (Total carot.), chlorophyll $a(\mathrm{Cl} a)$, chlorophyll $b(\mathrm{Cl} b)$, total chlorophyl $(\mathrm{Cl}$ total), SPAD index (SPAD), reducing sugars in the leaves $\left(\mathrm{RS}_{\text {leaf }}\right)$, reducing sugars in the stem above grafting point $\left(\mathrm{SRS}_{\mathrm{ab}}\right)$, reducing sugar in the stem below grafting point $\left(\mathrm{SRS}_{\mathrm{bl}}\right)$, reducing sugars in the roots $\left(\mathrm{RS}_{\text {root }}\right)$, total soluble sugars in the leaves $\left(\mathrm{TSS}_{\text {leaf }}\right)$, total soluble sugars in the stem above grafting point $\left(\mathrm{STSS}_{\mathrm{ab}}\right)$, total soluble sugars in the stem below grafting point $\left(\mathrm{STTS}_{\mathrm{bl}}\right)$, total soluble sugars in the roots $\left(\mathrm{TSS}_{\text {root }}\right)$, starch in the leaves $\left(\mathrm{STARCH}_{\text {leaf }}\right)$, starch in the stem above grafting point $\left(\mathrm{STARCHS}_{\mathrm{ab}}\right)$, starch in the stem below the grafting point $\left(\mathrm{STARCHS}_{\mathrm{ab}}\right)$, starch in the roots $\left(\mathrm{STARCH}_{\mathrm{root}}\right)$. Red ellipses indicate negative correlation, while blue ones indicate positive correlation. The thinner the ellipse, the greater the correlation between the variables.

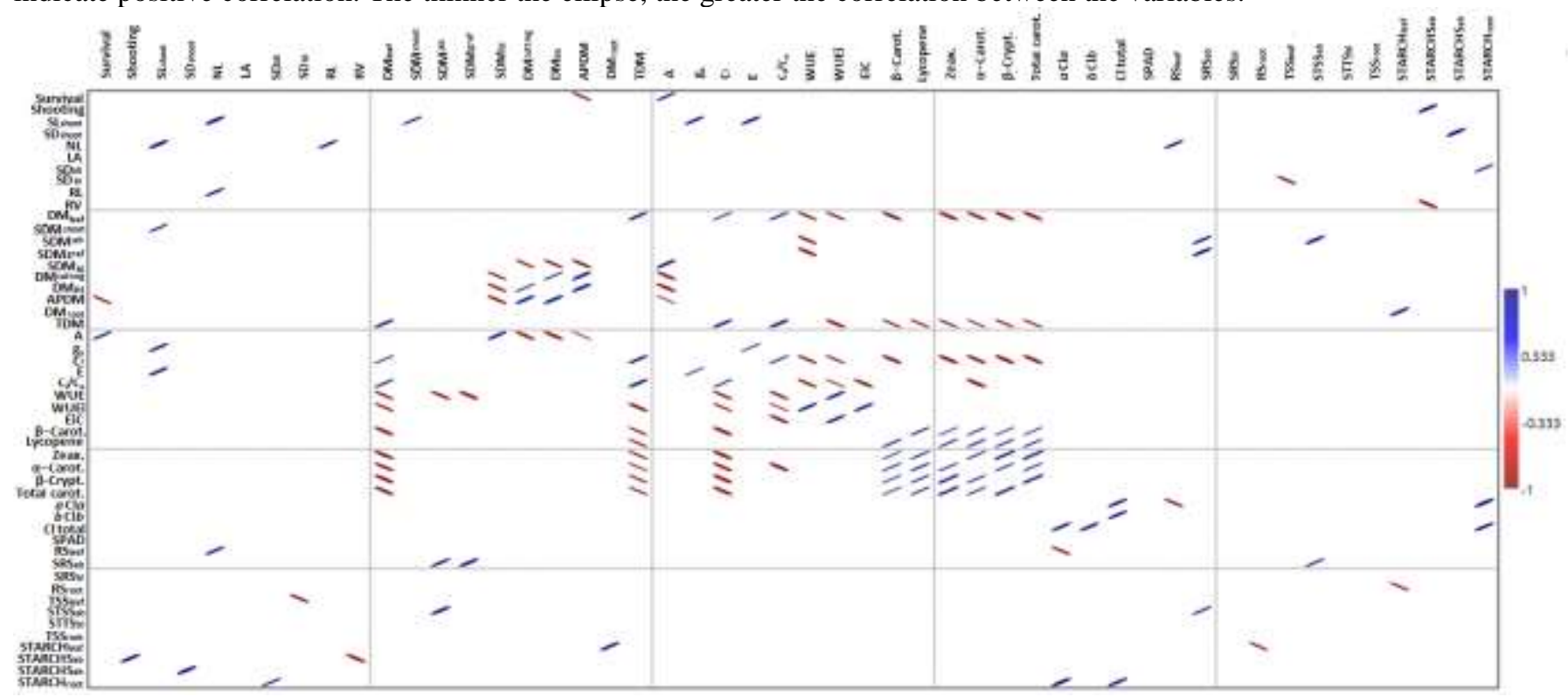

Source: Authors.

The TSS content in the stem below the grafting point was positively correlated with the accumulation of dry mass and RS of the stem above the grafting point. The starch content of the leaf correlated positively with the root dry mass and inversely with the root RS. The starch content of the stem above the grafting point was directly proportional to 
the shoot and inversely to the root volume. The starch content of the stem below the grafting point was directly proportional to the shoot diameter. The starch content of the root was positively correlated with the stem diameter above the grafting point and with the content of $a$-and total chlorophyll.

\section{Discussion}

The homograft did not differ from the other rootstocks and the average survival (78\%) and shooting (60\%) rates, it was possible to observe that all interspecific rootstocks ( $P$. aduncum, P. hispidum) and intraspecific ('Kottanadan') have initial compatibility with 'Bragantina'.

Studies on grafting using different plant species show that signs of incompatibility can occur in the early or late phase, identified between three to five years after grafting (Williams et al., 2021). P. tuberculatum showed initial incompatibility with 'Bragantina' black pepper, caused by the absence of connection at the grafting point, with graft elimination over time.

It is known that one of the main factors responsible for the incompatibility is the union between the graft and the rootstock, which does not occur adequately, causing several losses in the primary metabolism (Albrecht et al., 2019). Although a reduced percentage survived until 110 days after the experiment was conducted (34.5\%), about 40 days later, the grafts died.

The incompatibility between P. tuberculatum and 'Bragantina' did not allow the establishment of the aerial part of the graft. P. tuberculatum has a high vegetative vigor, observed by the excessive shooting at the base of the rootstock, which, even after eliminating the graft, remained alive and emitting buds. Grafting studies with other species evidence that very vigorous rootstocks often do not allow the establishment of a union with the graft, with high mortality (Li et al., 2017). This is because the energy and carbon skeletons needed to establish the new vascular system to connect the graft and the rootstock and to establish a new functional plant are directed to the shooting of the rootstock, which invests in the formation of a new canopy instead of consolidating the connection (Daley \& Hassell, 2014).

Another explanation for the incompatibility observed for $P$. tuberculatum is the absence of the production of mucilage tissue after cutting the rootstock. In all other rootstocks, the production of mucilage was observed when it was sectioned, which may have helped to reduce the occurrence of oxidation in the cutting region as suggested by Garner and Beakbane (1968).

The analysis of survival overtime allowed the identification of two critical stages in the grafting process through a lateral cleft, one at the moment when the plastic bags were removed from the graft and the other after the decapitation of the aerial part of the graft. The fall in survival may be related to the removal of plastic as observed by Wendling et al., (2016). This is probably due to exposure to the surface, which was not yet well welded, leaving it exposed to oxidation and moisture infiltration. Both stages are related to processes with high energy demand and indicate a limitation in the transfer of energy to keep the graft shooting. The fact that the type of container also influences the welding between the graft and rootstock is because the formation of the joint is closely correlated to root development, and hydraulic resistance (Adams et al., 2018), since, a direct correlation between root length and shoot development was observed.

The grafting of black pepper on native species of the genus Piper is a common practice in countries like India, where Piper colubrinum is the main species used as a rootstock (Vanaja et al., 2007). According to the literature, the survival of Panniyur-1 cultivar seedlings (registered as 'Bragantina' in Brazil) grafted depends on the rootstock, with greater success obtained with the use of $P$. colubrinum, with the survival of $76.2 \%$ (Chinnapappa et al., 2018), 86\% (Lakshmana et al., 2016) and varying between $25 \%$ to $100 \%$ depending on the time of year (Vanaja et al., 2007).

Studies carried out with other rootstocks indicate that survival depends on the rootstock and the cultivar. In the study by Aarthi and Kumar (2019), survival was $60 \%$ with the rootstock Piper hymenophyllum and $42 \%$ with Piper attenuatum, while in the study by Chinnapappa et al. (2018), survival was 38.9\% with IISR Sakthi and approximately $45 \%$ for Piper 
argyrophyllum and 58\% for IISR Thevam. However, the species evaluated as intraspecific and interspecific rootstocks in our trialwere never tested in the grafting of black pepper, so the results of this study are novel.

In addition to the interaction between graft and rootstock, other factors determine the success of the grafting, such as the method used and the time when grafting is performed. The most used method for grafting black pepper 'Panniyur-1' in wild species of the genus Piper is top-slit grafting (Chinnapappa et al., 2018; Lakshmanaet al., 2016; Vanaja et al., 2007). Recently, Aarthi and Kumar. (2019)evaluated another method of grafting, denominated "Stenting", in which the union of the graft and the formation of adventitious roots occurs simultaneously. A survival of $41.11 \%$ of the Panniyur-1 grafted under $P$. hymenophyllum was observed.

No studies were found in the literature that evaluated lateral grafting in a full cleft. In this technique, the aerial part is preserved until the formation of the shoot. Moreover, it is a method recommended for fruit trees, providing greater growth, accumulation of dry matter of the plant, and the dry mass of the root system, being more susceptible to survival (De Paiva et al., 2015; Kulaç \& Nayir, 2021). This technique was chosen in this test due to evidence of better survival made in preliminary tests.

Regarding the effect of the grafting season, Vanaja et al. (2007), in a preliminary study with genotypes of black pepper grafted on Piper colubrinum, conducted in the Panniyur region, Kerala, India, found that the largest survival (100\%) was in late winter/early spring, a period of less rainfall. The region's climate is quite different from ours, but the thermal conditions during the period that they observed the best survival are similar to the months of conduction of this grafting experiment. However, rainfall is quite different, with great variation in incident radiation, which directly interferes with photosynthesis and vegetative development, influencing the success of grafting. Therefore, it is important to carry out studies in Brazil, especially in producing regions, to better understand the effect of the environment on the grafting of black pepper, to isolate the environment effect.

It was found in this experiment that the evaluated rootstocks did not influence the photosynthetic capacity of the graft (chlorophyll content, SPAD index, and gas exchange) and consequently did not alter various parameters of seedling development or the production capacity of RS and TSS in the leaves.

Interestingly, the levels of carotenoids were higher in rootstocks compared to homograft, which may be an indication of the occurrence of stress caused by intra- and interspecific union. This greater accumulation of carotenoids may play an important role as a non-enzymatic antioxidant, where lycopene is the main antioxidant carotenoid, whose increase indicates the presence of stress (Kiran et al., 2019). Therefore, the antioxidant capacity of carotenoids probably guaranteed homeostasis in reactive oxygen species produced by the stress of grafting, promoting greater protection to the photosynthetic apparatus, thus assuring its functioning.

An interesting characteristic observed among the evaluated rootstocks was the greater length of the root system of $P$. hispidum, which reached values about 50\% higher than the others. On the other hand, 'Kottanadan' allocated $70 \%$ less dry matter to the root system than other rootstocks. The development of the root system may be an important feature for the better efficiency of water use under conditions of water shortage and it should be evaluated in further trials to better understand this effect (Franck et al., 2020).

According to Dias et al. (2013), the lower development of seedlings may be associated with the stress suffered in the grafting process or even due to incompatibility between the graft and rootstock. However, the largest accumulation of dry mass in the aerial part of the seedlings and the stem of the rootstock observed with the use of the homograft and 'Kottanadan' occurred due to the presence of the cutting, resulting from the cutting process to obtain the rootstocks of the cultivars. This cutting has a significant amount of dry mass, which represents $81 \%$ of the mass of the rootstock stem. Therefore, this greater 
accumulation of mass cannot be an indication of better seedling quality, considering that it did not alter the total dry mass of the seedling.

The characterization of incompatibility is not a simple process as there may be survival and later development of incompatibility symptoms due to failure in the union or development of abnormal conditions, growth patterns, and accumulation of carbohydrates (Priyanka et al., 2019). Despite the percentage of survival, the photosynthetic characteristics and quality of the seedling indicate that there was no incompatibility between 'Bragantina' and the rootstocks $P$. aduncum, $P$. hispidum, and 'Kottanadan', the evaluation of the relationship between the diameters and dry mass of the stem below and above the grafting point, as well as the allocation of carbohydrates to the different evaluated organs, in comparison with the homograft, indicated that the connection between the graft and the rootstock did not occur properly.

Poorly-connected grafts restrain transport in xylem and phloem, promoting the accumulation of carbohydrates in the upper parts of the plant leading to incompatibility (Zarrouk et al., 2010; Albrecht et al., 2019). These incompatibility signs are perceived mainly in the long term, as over the development of the plant there is an inadequate allocation of carbohydrates and nutrients, which leads to metabolic stress, which may result in the death of the plants (Goldschmidt, 2014; Baron et al., 2019). It is likely that the defective connections between black pepper and wild species are the causes of plant death in the field after four years of observation by Alconero et al. (1972) and Barriga (1986), using P. colubrinum as a rootstock.

The relationship between the diameters above and below the grafting point is considered an important indicator of morphological incompatibility (Machado et al., 2017) and may be caused by the differences in vigor between the graft and rootstock, which can lead to a mismatch between the vascular systems in the grafting region with plant development (Foster et al., 2017; Tamilselvi \& Pugalendhi, 2017; Dalzochio et al., 2021). In our test, only the homograft showed no differences between the diameters, therefore evidencing the existence of signs of incompatibility between the other rootstocks.

The larger diameter of the stem below the grafting point found in the rootstock P. aduncum is also the only material whose diameter below the grafting point was greater than the diameter above the grafting pointmay be indicative of incompatibility. However, according to Franco et al. (2018), the larger diameter in the rootstock than in the graft is desirable because it raises the pressure, which results in rapid distribution of the solutes throughout the plant structure. An interesting fact observed is that there was a greater depletion of TSS in the stem above the grafting point and a reduction of RS in the stem below and in the roots, indicating that the carbohydrates were being directed to other organs, such as the growth in diameter of the stem and shoots of the rootstock (Ferriani \& Krinski, 2019), considering that it was the species whose shoots were more intense. However, this greater drain force did not induce an increase in photosynthesis.

The observation on the transport of carbohydrates throughout the body of the plant allowed us to see that there is greater resistance in the passage of the TSS when transported by the grafting point in the rootstocks in comparison to the homograft. The production capacity in the leaf (source organ) is the same among the rootstocks since the values are equal for photosynthetic rate and TSS content. Considering then the differences in transport in the stem at the point above and at the point below the grafting, it appears that the lowest TSS value was in the homograft (43), followed by P. aduncum (62), from 'Kottanadan' (77) and P. hispidum (103). When we observed the differences between the diameters, we found that $P$. hispidum and 'Kottanadan' had higher TSS content and above diameter than the diameter below, leading to the conclusion that both rootstocks had limitations to the flow of carbohydrates.

Further, considering that the differences for wild species are intensified by the drainedstrength of the rootstock for the shoots at the base of the stem, we can infer that 'Kottanadan' had the greatest resistance to flow, probably due to defective vascular connections, resulting in less mass accumulation in the roots (69\% less than the others). We can also conclude that due to the reduced development of the roots, 'Kottanadan` had low drain strength, which limited the flow of carbohydrates 
Although no differences were observed between the rootstocks, the survival of the seedlings was positively correlated with the photosynthetic rate and inversely proportional to the dry mass of the aerial part. The efficiency of grafting depends on the reestablishment of vascular connections and any process that involves cell division and differentiation depends on energy and carbon skeletons, obtained mainly through photosynthesis. Besides, maintenance of the hydration of tissues is essential (Baron et al., 2019).

The study of correlations proved that less investment in aerial parts contributes to the reduction of stomatal conductance and transpiration and increases the efficiency of water use. However, a balance is necessary since an investment in leaves is necessary for the rise in $\mathrm{CO}_{2}$ inner concentration, in the ratio between the internal and external concentration of $\mathrm{CO}_{2}$, and in the production of reducing sugars in the leaves (Ibrahim et al., 2017; Zheng et al., 2019). Investment in the root system is also necessary as it maintains a balance between root and shoot (Rouphael et al., 2018), due to the positive correlation between the number of leaves and the length of the root.

Not only the ability to synthesize carbohydrates in the leaves, but their transport and allocation to the draining organs are decisive for the development of the grafted seedling. Greater photosynthesis allows the greater dry mass of the stem below the grafting point but reduces the dry mass of the aerial part of the seedling, which is a strong indicator of the draining force of the rootstock. The greater the accumulation of TSS in the leaves, the smaller the stem diameter below the grafting point, indicating that greater investment is occurring in the formation of the aerial part concerning the rootstock. The content of RS and TSS of the stem above the grafting point is decisive for the accumulation of dry mass in this region. Therefore, the allocation of carbohydrates can be used to understand the source-drain relationships in the grafting process.

\section{Conclusion}

The primary metabolism of Piper seedlings was affected by grafting, but only the interspecific grafting of 'Bragantina' under $P$. tuberculatum resulted in graft death, showing early incompatibility. Grafting on other rootstocks did not change survival, photosynthetic parameters and seedling quality. However, the analysis of carbohydrates and the differences in diameter above and below the grafting point, revealed alterations in the seedlings grafted on $P$. hispidum and 'Kottanadan' which may indicate late incompatibility. It was concluded that $P$. aduncum is the best rootstock for presenting greater initial compatibility among wild species, due to less impediment to carbohydrate flow.

It should be approached in further studies, the environmental factors (biotic and abiotic), the grafting period, the influence of the removal of plastic bags on survival and the understanding of mucilage secretion in the grafting welding process, as well as the relationship between drain-source must be studied for a better understanding of the grafting processes.

\section{References}

Aarthi, S., \& Kumar, N. (2019). Stenting Propagation-A Method in Black Pepper (Piper nigrum L.) Using Wild Species of Piper as Rootstock. International Journal of Innovative Horticulture, 8(1), 35-39.

Adams, S., Lordan, J., Fazio, G., Bugbee, B., Francescatto, P., Robinson, T. L., \& Black, B. (2018). Effect of scion and graft type on transpiration, hydraulic resistance and xylem hormone profile of apples grafted on Geneva ${ }^{8} 41$ and M. 9-NICTM 29 rootstocks.Scientia horticulturae,227, $213-222$.

Albrecht, U., Tripathi, I., Kim, H., \& Bowman, K. D. (2019). Rootstock effects on metabolite composition in leaves and roots of young navel orange (Citrus sinensis L. Osbeck) and pummelo (C. grandis L. Osbeck) trees. Trees, 33(1), 243-265.

Albuquerque, F. C. D., Duarte, M. D. L. R., Benchimol, R. L., \& Endo, T. (2001). Resistência de piperáceas nativas da Amazônia à infecção causada por Nectriahaematococcaf. sp. piperis. Acta Amazonica, 31(3), 341-341.

Alconero, R., Albuquerque, F., Almeyda, N., \& Santiago, A. G. (1972). Phytophthora foot rot of black pepper in Brazil and Puerto Rico.Phytopathology,62(1), $144-148$. 
Ambrozim, C. S., Furtado, J. G., Valani, R. S., Posse, R. P., Varnier, E., Posse, S. C. P., Dousseau, S., Arantes, L. \& de O. Oliveira, E. C. (2017). Propagação de pimenta do reino em diferentes concentrações de ácido indolbutírico. Revista Ifes Ciência, 3(2), 17-28.

Arnon, D. I. (1949). Copper enzymes in isolated chloroplasts. Polyphenoloxidase in Beta vulgaris. Plant Physiology, 24(1), 1-15.

Amri, R., Fonti, F. C., Giménez, R., Pina, A., \& Moreno, M. Á. (2021). Biochemical Characterization and Differential Expression of PAL Genes Associated With "Translocated" Peach/Plum Graft-Incompatibility. Frontiers in plant science, 12, 177.

Barriga, R. H. (1982). Pimenta-do-reino: origem e distribuição geográfica, caracteres botânicos e melhoramento genético. EMBRAPA/ CPATU.

Bastos, C. N., \& Santos, A. O. D. S. (2016). Porta-enxerto resistente a fusariose em pimenta-do-reino. Agrotropica, $28(2), 331-334$.

Baron, D., Amaro, A. C. E., Pina, A., \& Ferreira, G. (2019). An overview of grafting re-establishment in woody fruit species. Scientiahorticulturae, 243, 8491.

Baron, D., Saraiva, G. F. R., Amador, T. S., Rodrigues, J. D., Goto, R., \& Ono, E. O. (2018). Anatomical and physiological aspects of cucumber graft. Comunicata Scientiae, 9(2), 282-286.

Chinnapappa, M., Ramar, A., Pugalendhi, L., Muthulakshmi, P., \&Vetrivelkalai, P. (2019). Screening of Piper Species for Resistance to Quick Wilt caused by Phytophthoracapsici under Glasshouse Condition. Madras Agricultural Journal, 6, 77-84.

Daley, S. L., \& Hassell, R. L.(2014). Fatty alcohol application to control meristematic regrowth in bottle gourd and interspecific hybrid squash rootstocks used for grafting watermelon. HortScience, 49(3), 260-264.

Dalzochio, O. Â., Silvestre, W. P., \& Pauletti, G. F. (2021). Effect of the application of prohexadione-calcium on the growth of 'Packham's Triumph'and 'Hosui'pears (Pyrus communis L.). Research, Society and Development, 10(8), e3110816801-e3110816801.

De Paiva, E. P., Rocha, R. H. C., Sousa, F. A., Nobre, R. G., Guedes, W. A., Moreira, I. S., \& Sá, F. V. S. (2015). Crescimento e fisiologia de mudas de romãzeira cv. Wonderful propagadas por enxertia. Revista Brasileira de Ciências Agrárias, 10, 117-122.

Dias, F. P., C, A. M., Mendes, A. N. G., Vallone, H. S., Ferreira, A. D., \& De Rezende, J. C. (2013). Desenvolvimento de mudas de cultivares de café arábica enxertadas sobre Apoatã IAC 2258. Semina: Ciências Agrárias, 34(1), 29-36.

Dousseau, S., Alvarenga, A. A. D., Alves, E., Chaves, I. D. S., Souza, E. D. S., \&Alves, J. D. S. (2011). Características fisiológicas, morfológicas e bioquímicas da propagação sexual de Piper aduncum (Piperaceae). Brazilian Journal of Botany, 34(3), $297-305$.

FAO. Food and Agriculture of the United Nations. (2017). StatisticalDatabases. http://www.fao.org/faostat/en/

FERREIRA, D. F. (2011).Sisvar: a computerstatisticalanalysis system. Ciência e Agrotecnologia (UFLA).

Ferriani, A. P., \&Krinski, D. (2019). Effect of cuttings defoliation and different substrates on the vegetative propagation of the monkey-pepper (Piper aduncum L.) (Piperaceae). Revista Colombiana de Ciencias Hortícolas, 13(1), 130-136.

Foster, T. M., McAtee, P. A., Waite, C. N., Boldingh, H. L., \& McGhie, T. K. (2017). Apple dwarfing rootstocks exhibit an imbalance in carbohydrate allocation and reduced cell growth and metabolism. Horticultureresearch, 4(1), 1-13.

Franco, D. A., Arango, J. F., Hurtado-Salazar, A., \&Ceballos-Aguirre, N. (2018). Development, production, and quality of 'Chonto'type tomato grafted on cherry tomato introductions. Revista Ceres, 65(2), 150-157.

Franck, N., Zamorano, D., Wallberg, B., Hardy, C., Ahumada, M., Rivera, N., Montoya, M., Urra, C., Meneses, C., Balic, I., Mejía, N., Ibacache, A., \& Zurita-Silva, A. (2020).Contrasting grapevines grafted into naturalized rootstock suggest scion-driven transcriptomic changes in response to water deficit. ScientiaHorticulturae, 262, 1-12.

Garner, R., \&Beakbane, A. (1968). A Note on the Grafting and Anatomy of Black Pepper. Experimental Agriculture, 4(3), 187-192.

Goldschmidt, E. E. (2014). Plant grafting: new mechanisms, evolutionary implications. Frontiers in plant Science, 5, 1-9.

Hammer, Ø., Harper, D. A., \& Ryan, P. D. (2001). PAST: Paleontological statistics software package for education and data analysis. Palaeontologiaelectronica, 4(1), 9.

IBGE. Instituto Brasileiro de Geografia e Estatística-IBGE. (2018). Produção Agrícola nacional e regional. https://sidra.ibge.gov.br/Tabela/1613

Ibrahim, M. H., Jaafar, H. Z., \& Harun, M. H. (2017). Leaf Gas Exchange and Stomata Properties of Oil Palm Seedlings (Elaeisguineensis Jacq.) Progenies Exposed to Elevated Carbon Dioxide. Annual Research \& Review in Biology, 19(4) 1-13.

Joshi, D. R., Shrestha, A. C., \& Adhikari, N. (2018). A review on diversified use of the king of spices: Piper nigrum (black pepper). IJPSR, 9(10), 4089-4101.

Khayatnezhad, M., \& Nasehi, F. (2021). Industrial pesticides and a methods assessment for the reduction of associated risks: a Review. Advancements in Life Sciences, 8(2), 202-210.

Kiran, S., Bakhs, H. A., Iqbal, J., Iqbal, A., Raza, S., Ahmad, N., Ali, M. A., Danish, S. (2019). Effect of changing weather on success of wedge and veneer grafting and chlorophyll content in mango cv. SufaidChaunsa. International Journal of Biosciences, 14(2), 91-99.

Köppen, W. (1936). Das geographische system der klimat. in: Köppen, G. W \& Geiger, M. R. (Eds.), Handbuch der Klimatologie. Berlin: Gebrüder Bornträger, 1-44. 
Kulaç, Ş., \& Nayir, H. N. (2021). Determinação da adaptação de enxerto de alguns genótipos de castanha (Castanea sativa Mill.) Com a cultivar Marigoule (C. Sativa $\times$ C. Crenata). Turkish Journal of Agriculture-Food Science and Technology, 9 (8), 1555-1559.

Lakshmana, M., Hanumanthappa, M., \& Sunil, C. (2016). "Effect of propagation method on successful growth performance of pepper plants". In: Malhothra, S K, Kandiannan, K., Raj, K. M., Neema, V. P., Prasath, Srinivasan, D, Femina, H. C. V. Advances in planting material production technology in spices, Directorate of Arecanut and Spices Development, Kohzikode, Kerala, India. 18(4), 124-129.

Li, W., Fang, C., Krishnan, S., Chen, J., Yu, H., Murphy, A. S., Merewitz, E., Katin-Grazzini, L., Mcavoy, R. J., Deng, Z., Zale, J., \& Li, Y. (2017). Elevated auxin and reduced cytokinin contents in rootstocks improve their performance and grafting success. Plant biotechnology journal, 15(12), 1556-1565.

Machado, B. D., Magro, M., Rufato, L., Bogo, A., \&Kreztschmar, A. A. (2017). Graft compatibility between European pear cultivars and East Malling "C" rootstock. RevistaBrasileira de Fruticultura, 39(3), 1-9.

Miller, G. L. (1959). Use of dinitrosalicylic acid reagent for determination of reducing sugar. Analytical chemistry, 31(3), 426-428.

Priyanka, A., Sujatha, K. B., Sivakumar, T., \& Rajasree, V. (2019). Morphological changes in the compatible grafts of tomato cv. PKM 1 with different solanaceous rootstocks. Journal of Pharmacognosy and Phytochemistry, 8(3), 2416-2419.

Poorni, S., Priya, M., Rebecca, L. J., \& Sharmila, S. Partial Purification of Protease from Seaweed. International Journal of Applied Biotechnology and Biochemistry, 2(1), 81-85.

Rodriguez-Amaya, D. B., \& Kimura, M. (2004). HarvestPlus Handbook for Carotenoid Analysis. Washington: International Food Policy Research Institute (IFPRI).

Rouphael, Y., Kyriacou, M. C., \& Colla, G. (2018). Vegetable grafting: A toolbox for securing yield stability under multiple stress conditions. Frontiers in plant science, 8, 2255.

Schmildt, E. R., Arantes, L. De O., Hell, L. R., Lavanhole, D. F., \&Schmildt. O. (2018). Variedades de pimenta-do-reino. In: Silva. M.B., Da vitória, E. L. Campanharo, A. Cultura da pimenta-do-reino, Araçá.

Tamilselvi, N. A., \&Pugalendhi, L. (2017). Graft compatibility and anatomical studies of bitter gourd (Momordica charantia L.) scions with cucurbitaceous rootstocks. International Journal of Current Microbiology and Applied Sciences, 6(2), 1801-1810.

Thies, J. A. (2021). Grafting for managing vegetable crop pests. Pest Management Science, 77, 4825-4835.

Trindade, R., Almeida, L., Xavier, L., Andrade, E. H., Maia, J. G., Mello, A., William N., Ramos, A., da Silva, J. K. R. (2021). Influence on Secondary Metabolism of Piper nigrum L. by Co-Inoculation with Arbuscular Mycorrhizal Fungi and Fusarium solani f. sp. piperis. Microorganisms, 9(3), 484.

Vanaja, T., Neema, V. P., Rajesh, R., \& Mammootty, K. P. (2007). Graft recovery of Piper nigrum L. runner shoots on Piper colubrinum Link. rootstocks as influenced by varieties and month of grafting. Journal of Tropical Agriculture, 45, 61-62.

Vidoy-Mercado, I., Narváez, I., Palomo-Ríos, E., Litz, R. E., Barceló-Muñoz, A., \& Pliego-Alfaro, F. (2021). Reinvigoration/Rejuvenation Induced through Micrografting of Tree Species: Signaling through Graft Union. Plants, 10(6), 1197.

Wendling, I., Stuepp, C. A., \& Zuffellato-Ribas, K. C. (2016). Araucaria angustifolia grafting: techniques, environments and origin of propagation material. Bosque, 37(2), 285-293.

Williams, B., Ahsan, M. U., \& Frank, M. H. (2021). Getting to the root of grafting-induced traits. Current Opinion in Plant Biology, $59,101988$.

Yemm, E. W., \& Willis, A. (1954). The estimation of carbohydrates in plant extracts by anthrone. Biochemical journal, 57(3), 508-514.

Zanandrea, I., Bacarin, M. A., Braga, E. J. B., Bianchi, V. J., \& Peters, J. A. (2009). Morphological and physiological photon flux influence under in vitro culture of apple shoots. Brazilian Archives of Biology and Technology, 52(5), 1091-1098.

Zarrouk, O., Testillano, P. S., Risueño, M. C., Moreno, M. Á., \& Gogorcena, Y. (2010). Changes in cell/tissue organization and peroxidase activity as markers for early detection of graft incompatibility in peach/plum combinations. Journal of the American Society for Horticultural Science, 135(1), 9-17.

Zheng, Y., Li, F., Hao, L., Yu, J., Guo, L., Zhou, H., Ma, C., Zhang, X., \& Xu, M. (2019). Elevated $\mathrm{CO}_{2}$ concentration induces photosynthetic downregulation with changes in leaf structure, non-structural carbohydrates and nitrogen content of soybean. BMC plant biology, 19(1), 1-18. 